\title{
Effect of Oil Based Formulation of Trichoderma spp. on Growth Parameters of Cucumber Seedlings
}

\author{
B. Sreenayana and S. Nakkeeran* \\ Department of Plant Pathology, TNAU, Coimbatore - 03, Tamilnadu, India \\ *Corresponding author
}

Keywords

F. o. f. sp.

cucumerinum,

Growth parameters,

Oil based

formulation,

Trichoderma

Article Info

Accepted:

04 July 2019

Available Online:

10 August 2019

\section{A B S T R A C T}

Cucumber vascular wilt pathogen, Fusarium oxysporum f. sp. cucumerinum is one of the most destructive organisms that hampers the cucumber production under protected cultivation and results in huge economic loss to farmers. Trichoderma spp., a potent biocontrol agent screened against $F$. oxysporum f. sp. cucumerinum in vitro resulted that $T$. virens TRI 37 effectively inhibited the mycelial growth of pathogen to about $68.0 \%$ compared to other isolates. An oil based formulation of effective Trichoderma spp. was developed with initial conidial concentration of $1 \times 10^{10}$. The formulation remained stable for more than 180 days with conidial concentration of $1 \times 10^{8}$. Efficacy of oil based formulation on growth parameters of cucumber seedlings in protray experiments revealed that oil based formulation of $T$. virens TRI 37 effectively increased the shoot length $(28.74 \mathrm{~cm}, 14.54 \mathrm{~cm})$, root length $(14.64 \mathrm{~cm}, 19.14)$ and stem girth $(1.76 \mathrm{~cm}, 1.72 \mathrm{~cm})$ in comparison to other isolates in vermicompost: sand: soil (1:1:1) and coir pith medium respectively.

\section{Introduction}

Cucumber (Cucumis sativus L.) is one of the important vegetable crops, widely grown around the world. The leading producers of cucumber in world are China, Russia and Turkey, while India stands $27^{\text {th }}$ position in cucumber production. In India, cucumber is cultivated in an area of 1,07,500 ha with annual production and productivity of 1657 MT and 15.49 t/ha respectively as of 2018-19, whereas in Tamil Nadu, cucumber is cultivated in an area of 949 ha with an average production of $11,051 \mathrm{t} / \mathrm{ha}$ and with an average productivity of 11.58 t/ha and as of 2018-19. In recent days though cucumber cultivation is gaining momentum, the productivity of the crop is hampered due to the outbreak of pests and diseases in the protected cultivation. The continuous production of cucumbers in monoculture resulted in the occurrence of Fusarium wilt incited by Fusarium oxysporum 
f. sp. cucumerinum, which causes serious impact on cucumber cultivation all over the world (Ahmed, 2001). Monoculturing of cucumber for three continuous seasons increase the occurrence of Fusarium wilt as high as $70 \%$ with $10-50 \%$ reduction in the yield and thus resulting in complete crop failure (Chen et al., 2010; Booth 1971; Shen et al., 2008; Zhang et al., 2008) leading to a significant economic loss for farmers. The management of this disease includes the use of resistant cultivars, grafting, crop rotation and soil replacement (Yu, 2001). However, chemical control, often result in environmental and food quality problems (Minuto et al., 2006; Omar et al., 2006). As an alternative approach, the application of biocontrol agents to suppress soil borne pathogens has been widely used. The successful survival and colonization of beneficial antagonist in host plant are essential for the biocontrol of disease caused by $F$. $o$. f. sp. cucumerinum. Trichoderma spp. are non-pathogenic soilborne (free-living) fungi that colonize the roots of many plants as opportunistic, avirulent plant symbionts (Harman et al., 2004).

Success of any biocontrol agent depends on the type of formulation. Formulation also affect the shelf life of a product, ability of a biocontrol organism to multiply and survive in the environment, ability to control the disease, ease of preparation and application and cost of preparation and application. Biocontrol organisms have been formulated in variety of ways like wettable powders, dry flowable formulations, dusts, granules, liquids, gels, oil based formulations, pellets, freeze dried, spray dried and vaccum dried formulations for seed treatment, foliar application and soil application. Most of the biocontrol agent formulations are carrier based containing beneficial microorganisms in a viable state deliberated for seed or soil application (Sivasakthivelan and Saranraj, 2013). The liquid fermentation derived talc formulation of $T$. harzianum with the addition of glycerol in the production medium could protect the tomato plants from Fusarium wilt incidence by $44-50 \%$ (Sriram et al., 2011).

The current study was carried out to understand the effect of oil based formulation of Trichoderma spp. on growth parameters of cucumber seedlings in portray experiments. The shelf life of the oil based formulation was also studied.

\section{Materials and Methods}

\section{Fungal strains}

Fungal strains like $T$. virens (KU666466), $T$. koningiopsis (MF423101), T. asperellum (KX533985), T. koningiopsis (MF405092), T. harzianum (KX533990), T. harzianum (KX533990), T. harzianum (KX533989), $T$. asperelloides (MK981226) and F. o.f. sp. cucumerinum (KY495294) provided from the culture collection of Department of Plant Pathology, Tamil Nadu Agriculture University, Coimbatore and used in the following experiments.

\section{Screening of Trichoderma spp. against $F$.} oxysporum f. sp. cucumerinum

Seven different isolates of Trichoderma spp. were screened against $F$. o. f. sp.cucumerinum F1. A mycelial disc of the pathogen $(9 \mathrm{~mm}$ dia.) from the actively growing four day culture of the pathogen was placed at one end and a 9mm mycelial disc of the mycelium from the actively growing Trichoderma spp. was placed at the other end in Potato Dextrose Agar Medium (Potato - 250g, Dextrose - 20 g, Agar $-20 \mathrm{~g}$ and Distilled water -1 litre). The plates were incubated at $28 \pm 2{ }^{\circ} \mathrm{C}$ for seven days. The linear growth of the pathogen and antagonists were measured when the pathogen attained full growth in control plates. 
Per cent inhibition of the test pathogen by the antagonistic isolates was evaluated by dual culture technique (Dennis and Webster, 1971). The radial growth of mycelium in $\mathrm{cm}$ of pathogen and antagonists were measured and per cent inhibition of test pathogen by the antagonistic strain was evaluated by dual culture technique (Dennis and Webster 1971). The radial growth of mycelium in $\mathrm{mm}$ of pathogen and antagonists were measured and per cent inhibition (PI) was calculated $^{\mathrm{PI}}=\frac{\mathrm{C}-\mathrm{T}}{\mathrm{C}} \times 100$, where $\mathrm{C}$ is the growth of test pathogen $(\mathrm{mm})$ in the absence of the antagonist strain; $\mathrm{T}$ is the growth of test pathogen $(\mathrm{mm})$ in the presence of the antagonist strain. Total of three replications were maintained for each isolate and the experiment was repeated twice to confirm the results.

\section{Preparation of oil based formulation of Trichoderma spp.}

Based on the in vitro assay, the best four isolates (T. virens (KU666466), $T$. koningiopsis (MF423101), T. asperellum (KX533985) and T. asperelloides (MK981226)) with high conidial production was used for subsequent studies. The emulsion contained the following ingredients viz., $1 \%$ glycerol (as an osmoticant), 1\% PVP, $0.5 \%$ $\mathrm{ZnSO}_{4}$ (increases the shelf life), $1 \%$ Tween 20 (emulsifying agent), distilled water and coconut oil. The conidia of 4 effective Trichoderma spp. were mass multiplied in Potato Dextrose Agar medium for 5 days. After complete colonisation of the media, the conidia was collected by centrifuging at 6000 rpm for 5 minutes at $28 \pm 2^{\circ} \mathrm{C}$. The aqueous phase was prepared by adding $1 \%$ conidia, $1 \%$ glycerol, $1 \% \mathrm{PVP}$ and $0.5 \% \mathrm{ZnSO}_{4}$ in $80 \mathrm{ml}$ sterile distilled water and the oil phase was prepared by adding $1 \%$ tween $20 \mathrm{in} 20 \mathrm{ml}$ of coconut oil. The oil phase was then added to aqueous phase and stirred well. The $\mathrm{pH}$ of the formulation was adjusted to 6.5-7.0. All the formulation had an initial conidial concentration of $1 \times 10^{8}$ per ml. The prepared formulations were distributed in four different falcon tubes and stored at room temperature.

\section{Shelf life of oil based formulation of Trichoderma spp.}

The shelf life of the oil based formulation was recorded at monthly interval. The shelf life was assessed for a period of 180 days. The population was estimated by serially diluting the sample upto $10^{8}$ and subsequent plating on to Trichoderma Selective Medium (TSM) at $28 \pm 2{ }^{\circ} \mathrm{C}$. After 3 days conidial count was recorded. Four replications were maintained for each isolate.

Effect of oil based formulation of Trichoderma spp. on growth parameters of cucumber seedlings

The cucumber seeds cv. Green long were treated with oil based formulation of Trichoderma spp. $\left(1^{\times} 10^{7}\right)$ as per the following treatment schedule. The treated seeds were sown in protrays containing sterilised vermicompost: soil: sand (1:1:1) and coirpith. The seedlings were inoculated with oil based formulation at 7 th and 15 th day.

Five replications were maintained for each treatment with 25 seedlings/replication. The plants were grown for about 35 days. The growth parameters such as root length, shoot length, stem girth and no. of leaves were recorded.

\section{Statistical analysis}

All the experiments were analyzed independently. The treatment means were compared by Duncan's Multiple Range-Test (DMRT) (Gomez and Gomez, 1984). The package used for analysis was SPSS version 16.0.developed by IBM Corporation. 


\section{Results and Discussion}

In vitro screening of Trichoderma spp. against $F$. oxysporum f. sp. cucumerinum

Seven different isolates of Trichoderma spp. were screened for in vitro antagonism against F.oxysporum f. sp. cucumerinum $\mathrm{F} 1$ by dual culture technique. The in vitro efficacy of antagonism of different Trichoderma isolates revealed that the growth of $F$. oxysporum $\mathrm{f}$. sp. cucumerinum was suppressed maximum to an extent of 68.00 per cent over control by $T$. virens TRI 37 and was followed by $T$. koningiopsis TRI 41 and T. asperellum TRI 15 with 65.77 and 60.88 per cent inhibition respectively. $T$. koningiopsis TRI 44 had the lowest inhibition (44.88\%) on the mycelial growth of $F$. oxysporum f. sp. cucumerinum F1. The four effective isolates was used for further studies (Table 1).

\section{Shelf life of oil based formulation}

The population load of $T$. virens TRI 37 on zero day was $10.4 \times 10^{9} \mathrm{cfu} / \mathrm{ml}$. The final population after six months of storage was 3.1 x $10^{8} \mathrm{cfu} / \mathrm{ml}$. The population load of $T$. koningiopsis TRI 41 on zero day was $9.9 \times 10^{9}$ $\mathrm{cfu} / \mathrm{ml}$. The final population after six months of storage was $2.9 \times 10^{8} \mathrm{cfu} / \mathrm{ml}$. The population load of $T$. asperellum TRI 15 on zero day was $9.2 \times 10^{8} \mathrm{cfu} / \mathrm{ml}$. The final population after six months of storage was 2.9 $\mathrm{x} 10^{7} \mathrm{cfu} / \mathrm{ml}$. Similarly, the population load of T. asperelloides TNAU Tad 1 on zero day was $8.8 \times 10^{8} \mathrm{cfu} / \mathrm{ml}$. The final population after six months of storage was $2.8 \times 10^{7} \mathrm{cfu} / \mathrm{ml}$ (Table 2).

Effect of oil based formulation of Trichoderma spp. on growth parameters of cucumber seedlings

The effect of Trichoderma sp. on root length, shoot length and stem girth in both medium (vermicompost: soil: sand and coir pith) were presented in table entitled on effect of Trichoderma sp. on growth parameters of cucumber seedlings (Table 3).

\section{Shoot length}

Among the 10 treatments, shoot length was found to be more in the $T$. virens TRI 37 $(28.74 \mathrm{~cm})$ treated plants followed by $T$. asperelloides TNAU Tad $1(27.48 \mathrm{~cm})$ and $T$. koningiopsis

TRI $41(26.38 \mathrm{~cm})$ seed treated plants grown in vermicompost: soil: sand (1:1:1) medium whereas shoot length was found to be more in the $T$. asperelloides TNAU Tad $1(14.78 \mathrm{~cm})$ treated plants followed by $T$. virens TRI 37 (14.54 cm) and T. koningiopsis TRI 41 (14.30 $\mathrm{cm}$ ) seed treated plants grown in coir pith medium.

\section{Root length}

Among the 10 treatments, root length was found to be more in the T. virens TRI 37 $(14.64 \mathrm{~cm})$ treated plants followed by $T$. asperelloides TNAU Tad $1(14.58 \mathrm{~cm})$ and T.koningiopsis TRI $41(14.58 \mathrm{~cm})$ seed treated plants grown in vermicompost: soil: sand $(1: 1: 1)$ medium whereas root length was found to be more in the $T$. virens TRI $37(19.18 \mathrm{~cm})$ treated plants followed by $T$. asperelloides TNAU Tad1 $(19.08 \mathrm{~cm})$ and $T$. koningiopsis TRI $41(19.06 \mathrm{~cm})$ seed treated plants grown in coirpith medium.

\section{Stem girth}

Among the 10 treatments, stem girth was found to be more in the T. virens TRI 37 (1.76 $\mathrm{cm}$ ) treated plants followed by $T$. asperelloides TNAU Tad $1(1.66 \mathrm{~cm})$ and $T$. koningiopsis TRI $41(1.64 \mathrm{~cm})$ seed treated plants grown in vermicompost: soil: sand $(1: 1: 1)$ medium. 


\begin{tabular}{|c|c|}
\hline \multicolumn{2}{|r|}{ Treatment details } \\
\hline T1 & Healthy Control \\
\hline T2 & Inoculated Control (F.o. f. sp. cucumerinum F1 inoculated soil) \\
\hline T3 & Seed treatment with of oil based formulation (OB) of $T$. virens TRI 37 \\
\hline T4 & Seed treatment with oil based formulation (OB) of $T$. koningiopsis TRI 41 \\
\hline T5 & Seed treatment with oil based formulation $(\mathrm{OB})$ of $T$. asperellum TRI 15 \\
\hline T6 & $\begin{array}{l}\text { Seed treatment with oil based formulation (OB) of } T \text {. virens TRI } 37 \text { in } F . o \text {. f.sp. } \\
\text { cucumerinum } \mathrm{F} 1 \text { (FOC) inoculated soil }\end{array}$ \\
\hline T7 & $\begin{array}{l}\text { Seed treatment with oil based formulation (OB) of T. koningiopsis TRI } 41 \text { in } F . o \text {. } \\
\text { f.sp. cucumerinum } \mathrm{F} 1 \text { (FOC) inoculated soil }\end{array}$ \\
\hline T8 & $\begin{array}{l}\text { Seed treatment with oil based formulation (OB) of T. asperellum TRI } 15 \text { in } F . o \text {. f.sp. } \\
\text { cucumerinum } \mathrm{F} 1 \text { (FOC) inoculated soil }\end{array}$ \\
\hline T9 & Seed treatment with oil based formulation (OB) of T. asperelloides TNAU Tad 1 \\
\hline T10 & $\begin{array}{l}\text { Seed treatment with oil based formulation (OB) of T. asperelloides TNAU Tad } 1 \text { in } \\
\text { F. o. f.sp. cucumerinum } \mathrm{F} 1 \text { (FOC) inoculated soil }\end{array}$ \\
\hline
\end{tabular}

Table.1 In vitro antagonistic activity of Trichoderma spp. against $F$. $o$. f. sp. cucumerinum

\begin{tabular}{|c|c|c|c|}
\hline Treatments & $\begin{array}{c}\text { Growth of the } \\
\text { pathogen* }\end{array}$ & $\begin{array}{c}\text { Growth of the } \\
\text { antagonist* }^{*}\end{array}$ & $\begin{array}{c}\text { Percent inhibition } \\
\text { over control** }^{*}\end{array}$ \\
\hline T. virens & $2.88^{\mathrm{a}}$ & $6.12^{\mathrm{a}}$ & $68.00^{\mathrm{a}}$ \\
TRI 37 & $(1.70)$ & $(2.48)$ & $(56.22)$ \\
\hline T. asperellum & $3.52^{\mathrm{b}}$ & $5.48^{\mathrm{ab}}$ & $60.88^{\mathrm{b}}$ \\
TRI 15 & $(1.88)$ & $(2.35)$ & $(51.93)$ \\
\hline T. koningiopsis & $3.08^{\mathrm{a}}$ & $5.92^{\mathrm{b}}$ & $65.77^{\mathrm{a}}$ \\
\hline TRI 41 & $(1.75)$ & $(2.44)$ & $(54.86)$ \\
\hline T. koningiopsis & $4.96^{\mathrm{d}}$ & $4.04^{\mathrm{c}}$ & $44.88^{\mathrm{d}}$ \\
\hline TRI 44 & $(2.23)$ & $(2.02)$ & $(47.28)$ \\
\hline T. harzianum & $4.04^{\mathrm{c}}$ & $4.96^{\mathrm{b}}$ & $55.11^{\mathrm{cd}}$ \\
\hline TRI 36 & $(2.01)$ & $(2.24)$ & $(48.56)$ \\
\hline T. harzianum & $3.68^{\mathrm{bc}}$ & $5.32^{\mathrm{ab}}$ & $59.11^{\mathrm{bc}}$ \\
\hline TRI 35 & $(1.91)$ & $(2.32)$ & $(50.89)$ \\
\hline T. asperelloides & $3.62^{\mathrm{bc}}$ & $5.38^{\mathrm{ab}}$ & $59.77^{\mathrm{bc}}$ \\
\hline TNAU-Tad1 & $(1.90)$ & $(2.33)$ & $(51.29)$ \\
\hline Untreated Control & $9.00^{\mathrm{e}}$ & $0.00^{\mathrm{d}}$ & - \\
\hline
\end{tabular}

(Values are means of three replications, *Values in the parenthesis are square root transformed values, ** Values in the parenthesis are arcsine transformed values and followed by a common letter are not significantly different at $5 \%$ level by DMRT) 
Table.2 Shelf life of oil based formulation of Trichoderma spp.

\begin{tabular}{|c|c|c|c|c|c|c|c|}
\hline \multirow[t]{2}{*}{ Treatments } & \multicolumn{7}{|c|}{ Colony forming units $(\mathrm{cfu} / \mathrm{ml})^{*}$} \\
\hline & $\begin{array}{c}0^{\text {th }} \text { day } \\
\left(10^{8} \mathrm{cfu} / \mathrm{ml}\right)\end{array}$ & $\begin{array}{c}30^{\text {th }} \text { day } \\
\left(10^{8} \mathrm{cfu} / \mathrm{ml}\right)\end{array}$ & $\begin{array}{c}60^{\text {th }} \text { day } \\
\left(10^{8} \mathrm{cfu} / \mathrm{ml}\right)\end{array}$ & $\begin{array}{c}90^{\text {th }} \text { day } \\
\left(10^{8} \mathrm{cfu} / \mathrm{ml}\right)\end{array}$ & $\begin{array}{c}120^{\text {th }} \text { day } \\
\left(10^{7} \mathrm{cfu} / \mathrm{ml}\right)\end{array}$ & $\begin{array}{c}150^{\text {th }} \text { day } \\
\left(10^{7} \mathrm{cfu} / \mathrm{ml}\right)\end{array}$ & $\begin{array}{c}180^{\text {th }} \text { day } \\
\left(10^{7} \mathrm{cfu} / \mathrm{ml}\right)\end{array}$ \\
\hline $\begin{array}{c}\text { T. virens } \\
\text { TRI } 37\end{array}$ & $\begin{array}{c}104^{\mathrm{a}} \\
(2.02)\end{array}$ & $\begin{array}{c}81^{\mathrm{a}} \\
(1.91)\end{array}$ & $\begin{array}{c}75^{\mathrm{a}} \\
(1.96)\end{array}$ & $\begin{array}{c}72^{\mathrm{a}} \\
(1.86)\end{array}$ & $\begin{array}{c}42^{\mathrm{a}} \\
(1.51)\end{array}$ & $\begin{array}{c}37^{\mathrm{a}} \\
(1.42)\end{array}$ & $\begin{array}{c}31^{\mathrm{a}} \\
(1.49)\end{array}$ \\
\hline $\begin{array}{l}\text { T. koningiopsis } \\
\text { TRI } 41\end{array}$ & $\begin{array}{c}99^{\mathrm{b}} \\
(1.99)\end{array}$ & $\begin{array}{c}80^{\mathrm{a}} \\
(1.90)\end{array}$ & $\begin{array}{c}72^{b} \\
(1.85)\end{array}$ & $\begin{array}{c}63^{b} \\
(1.79)\end{array}$ & $\begin{array}{c}39^{\mathrm{b}} \\
(1.59)\end{array}$ & $\begin{array}{c}36^{\mathrm{a}} \\
(1.41)\end{array}$ & $\begin{array}{c}29^{b} \\
(1.46)\end{array}$ \\
\hline $\begin{array}{c}\text { T. asperellum } \\
\text { TRI } 15\end{array}$ & $\begin{array}{c}92^{c} \\
(1.96)\end{array}$ & $\begin{array}{c}78^{\mathrm{b}} \\
(1.89)\end{array}$ & $\begin{array}{c}68^{c} \\
(1.83)\end{array}$ & $\begin{array}{c}58^{\mathrm{c}} \\
(1.76)\end{array}$ & $\begin{array}{c}37^{\mathrm{c}} \\
(1.43)\end{array}$ & $\begin{array}{c}35^{\mathrm{a}} \\
(1.40)\end{array}$ & $\begin{array}{c}29^{\mathrm{b}} \\
(1.46)\end{array}$ \\
\hline
\end{tabular}

(Values are means of four replications, values in the parenthesis are log transformed values, values followed by a common letter are not significantly different at $5 \%$ level by DMRT) 
Table.3 Effect of oil based formulation of Trichoderma spp. on growth parameters of cucumber seedlings

\begin{tabular}{|c|c|c|c|c|c|c|c|c|}
\hline \multirow[t]{2}{*}{ Treatments } & \multicolumn{8}{|c|}{ Growth Parameters } \\
\hline & \multicolumn{4}{|c|}{ Vermicompost : Soil : Sand (1:1:1) } & \multicolumn{4}{|c|}{ Coir pith } \\
\hline Healthy Control & $11.42^{\mathrm{d}}$ & $22.96^{\mathrm{g}}$ & $1.38^{\mathrm{d}}$ & $5.6^{\mathrm{d}}$ & $17.30^{\mathrm{bc}}$ & $12.96^{\mathrm{b}}$ & $1.56^{\mathrm{bc}}$ & $4.6^{\mathrm{d}}$ \\
\hline $\begin{array}{l}\text { ST with OB formulation of } T \text {. koningiopsis TRI } \\
41\end{array}$ & $14.58^{\mathrm{a}}$ & $26.38^{\mathrm{cd}}$ & $1.64^{\mathrm{ab}}$ & $6.6^{\mathrm{ab}}$ & $19.06^{\mathrm{a}}$ & $14.30^{\mathrm{a}}$ & $1.68^{\mathrm{ab}}$ & $5.2^{\text {bcd }}$ \\
\hline ST with OB formulation of $T$. virens TRI 37 & $14.88^{\mathrm{a}}$ & $28.74^{\mathrm{a}}$ & $1.76^{\mathrm{a}}$ & $6.8^{\mathrm{a}}$ & $19.18^{\mathrm{a}}$ & $14.54^{\mathrm{a}}$ & $1.72^{\mathrm{a}}$ & $5.2^{\mathrm{bcd}}$ \\
\hline $\begin{array}{l}\text { ST with OB formulation of } T \text {. virens TRI } 37 \text { in } \\
\text { FOC inoculated soil }\end{array}$ & $13.84^{\mathrm{ab}}$ & $26.94^{\mathrm{bc}}$ & $1.62^{\mathrm{abc}}$ & $6.6^{\mathrm{ab}}$ & $17.34^{\mathrm{bc}}$ & $14.04^{\mathrm{a}}$ & $1.64^{\mathrm{ab}}$ & $5.0^{\mathrm{cd}}$ \\
\hline $\begin{array}{l}\text { ST with OB formulation of } T \text {. asperellum in FOC } \\
\text { inoculated soil }\end{array}$ & $12.82^{\mathrm{bc}}$ & $24.52^{\mathrm{f}}$ & $1.58^{\mathrm{bc}}$ & $6.0^{\mathrm{bcd}}$ & $18.14^{\mathrm{ab}}$ & $14.58^{\mathrm{a}}$ & $1.66^{\mathrm{ab}}$ & $6.2^{\mathrm{ab}}$ \\
\hline ST with OB formulation of $T$. asperelloides & $14.64^{\mathrm{a}}$ & $27.48^{b}$ & $1.66^{\mathrm{ab}}$ & $6.6^{\mathrm{ab}}$ & $19.08^{\mathrm{a}}$ & $14.78^{\mathrm{a}}$ & $1.66^{\mathrm{ab}}$ & $6.4^{\mathrm{a}}$ \\
\hline $\begin{array}{l}\text { ST with OB formulation of } T \text {. asperelloides in } \\
\text { FOC inoculated soil }\end{array}$ & $13.82^{\mathrm{ab}}$ & $25.30^{\mathrm{ef}}$ & $1.62^{\mathrm{abc}}$ & $6.0^{\mathrm{bcd}}$ & $17.74^{b c}$ & $14.28^{\mathrm{a}}$ & $1.58^{b c}$ & $6.2^{\mathrm{ab}}$ \\
\hline
\end{tabular}


Whereas stem girth was found to be more in the $T$. virens TRI $37(1.72 \mathrm{~cm})$ treated plants followed by $T$. koningiopsis TRI $41(1.68 \mathrm{~cm})$ and $T$. asperelloides TNAU Tad $1(1.66 \mathrm{~cm})$ seed treated plants grown in coirpith medium.

Trichoderma spp. were considered as the potential biocontrol agents for the control of phytopathogenic fungi, oomycetes, and even nematodes (Monte 2001). Similarly in the present investigation $T$. virens TRI 37 inhibited the mycelia growth of the pathogen upto $68.00 \%$ followed by T. koningiopsis TRI 41 and $T$. asperellum TRI 15 . The results were similar with the findings of Saravanakumar et al., (2016). They screened 100 isolates of Trichoderma spp. and reported that $T$. asperellum strain CCTCC-RW0014 was effective against $F . \quad o$. f. $\mathrm{sp}$. cucumerinum. The in vitro studies confirmed the maximum antifungal activity of $T$. virens TRI37 against cucumber wilt pathogen (Vasumathi et al., 2016). Similarly, Lopes et al., (2012) screened 21 isolates of Trichoderma spp. and reported that $T$. asperellum inhibited $S$. sclerotiorum to an extent of $50 \%$. These findings confirm the effect of Trichoderma spp. in inhibiting the mycelial growth of $F$. o. f. sp. cucumerinum in vitro.

In protray experiments, $T$. koningiopsis TRI 41 treated seedlings had more root length, shoot length, stem girth and no. of leaves compared to other isolates. When soil was amended with $T$. harzianum propagules, a $30 \%$ increase in seedling emergence was observed up to 8 days after sowing. On day 28, these plants exhibited a 95 and $75 \%$ increase in root area and cumulative root length, respectively, and a significant increase in dry weight (80\%), shoot length $(45 \%)$ and leaf area (80\%). Similarly, an increase of $90 \%$ and $30 \%$ in $\mathrm{P}$ and $\mathrm{Fe}$ concentration respectively, was observed in $T$. harzianum inoculated plants of cucumber
(Yedidia et al., 2001). Similarly, Trichoderma harzianum isolate T969 increased the vigor and their nutrient uptake of tomato plants. Seed germination rate was not affected by Trichoderma application, but shoot height, shoot diameter, shoot fresh and dry weight and root fresh and dry weight in tomato seedlings were increased when sown in $T$. harzianum T969 fortified soil and when compared to the control (Azarmi et al., 2011). These results indicate the positive effect of Trichoderma spp. on growth parameters of cucumber plants.

The success of any biocontrol agent depends on the type of formulation. In the present study, oil based formulation of Trichoderma spp. such as $T$. koningiopsis TRI 41, $T$. asperellum TRI 15 and $T$. asperelloides TNAU Tad 1 was developed. The population load of T. koningiopsis TRI 41 on zero day was $10.4 \times 10^{8} \mathrm{cfu} / \mathrm{ml}$. The final population after six months of storage was $3.1 \times 10^{7} \mathrm{cfu}$ $/ \mathrm{ml}$. This is confirmed with the findings of Mbarga et al., (2014), where they developed an oil based formulation of T. asperellum was for the control of cocao black pod disease caused by Phytophthora megakarya with a shelf life of about 22.5 weeks and conidial concentration of about $2.7^{\times} 10^{7}$ conidia/ml. This oil based formulation contained different additives such as vegetable oil (soybean oil 74\%), emulsifying agent (Tensiofix NTM$15 \%$ ), Structural agent (Tensiofix 869-5\%), carbon cource (Glucose-4\%) and $T$. asperellum conidia (2\%). The formulation showed complete inhibition of P.megakarya on sprayed detached pods and there was enhanced rate and duration of protection on sprayed cocao pods in field with $50 \%$ of pods protected for 3.2 weeks after spraying in field. This formulation was developed with an intension to supply for small cocao producers. Similarly, an invert emulsion (water in oil) of T. harzianum Rifai has been developed for the control of post-harvest diseases of fresh fruits 
caused by Botrytis cinerea, Rhizopus stolonifer and Pencillium expansum. The invert emulsion consisted of sterile deionized water $(45.25 \%)$, glycerine $(4 \%)$, water soluble wax $(0.75 \%)$, tween $20(2.5 \%)$ and a mixture of coconut oil (19\%) and soybean oil (28.5\%) with a conidial concentration of about $4.6^{\times} 10^{8} \quad$ conidia/ml of emulsion. $T$. harzianum Rifai containing conidia reduced the mean lesion diameter of $R$. stolonifer on apple, pear, peach and strawberry, B.cinerea on grape, pear, strawberry and kiwi fruit and $P$. expansum on grape, pear and kiwi fruit compared to control. The mean duration of minimum protection period was upto 59 days and percent reduction of disease was about $89 \%$ on unwounded apple fruit against infection with $R$. stolonifer (Batta, 2006).

In conclusion, the production of oil based formulation of Trichoderma spp. from locally available oil and emulsifiers resulted in increased vigor and growth parameters in protray experiments with increased shelf life. However, the efficacy of formulation under protected cultivation has to be evaluated.

\section{References}

Ahmed GA. 2010. Controlling of Fusarium Wilt of Cucumber by Antagonistic Bacteria. J. Life Sci 4(7): 16-21.

Azarmi R, Hajieghrari B and Giglou A. (2011). Effect of Trichoderma isolates on tomato seedling growth response and nutrient uptake. African Journal of Biotechnology, 10(31), 5850-5855.

Batta, Yacoub A. 2007. "Control of postharvest diseases of fruit with an invert emulsion formulation of Trichoderma harzianum Rifai." Postharvest Biology and technology 43 (1): 143-150.

Booth C. 1971. The genus Fusarium. CMI, Kew, pp 145-147

Chen LH, Yang XM, Raza W, Li JH, Liu YX,
Qiu MH, Zhang FG, Shen QR. 2010. Trichoderma harzianum SQR-T037 rapidly degrades allelochemicals in rhizospheres of continuously cropped cucumbers. Appl Microbiol Biotechnol. 89(5):1653-1663

Dennis C and Webster J. 1971. Antagonistic properties of species groups of Trichoderma I Production of nonvolatile antibiotics. Trans. $\mathrm{Br}$ Mycol Soc 57: 25-39.

Gomez KA and Gomez AA. 1984. Statistical Procedure for Agricultural Research.John Wiley and Sons, New York.

Harman GE, Howell CR, Viterbo A, Chet I and Lorito M. 2004. Trichoderma species - opportunistic, avirulent plant symbionts. Nature Rev Microbiol 2: 4356.

Li Y, Sun R, Yu J, Saravanakumar K and Chen J. 2016. Antagonistic and Biocontrol Potential of Trichoderma asperellum ZJSX5003 against the Maize Stalk Rot Pathogen Fusarium graminearum. Indian J Microbiol 56(3): 318-327

Lopes, Cardoso FA, Steindorff AS, Geraldine AM, Brandão RS, Monteiro VN, Júnior ML, Coelho ASG and Silva RN. 2012. "Biochemical and metabolic profiles of Trichoderma strains isolated from common bean crops in the Brazilian Cerrado, and potential antagonism against Sclerotinia sclerotiorum." Fungal Biology 116 (7): 815-824.

Mbarga, Bienvenu J, BAD Begoude, Ambang Z, Meboma M, Kuaté J, Schiffers B, Ewbank W, Dedieu L, and Hoopen GMT. 2014. "A new oil-based formulation of Trichoderma asperellum for the biological control of cacao black pod disease caused by Phytophthora megakarya." Biological Control 77: 1522.

Minuto A, Davide S, Garibaldi A, Gullino 
ML. 2006. Control of soilborne pathogens of tomato using a commercial formulation of Streptomyces griseoviridis and solarization. Crop Prot 25: 468-475

Omar I, O’Neill T, Rossall S. 2006. Biological control of Fusarium crown and root rot of tomato with antagonistic bacteria and integrated control when combined with the fungicide carbendazim. Plant Pathol 55: 92-99

Saravanakumar K, Yu C, Dou K, Wang M., Li Y and Chen J. 2016. Synergistic effect of Trichoderma-derived antifungal metabolites and cell wall degrading enzymes on enhanced biocontrol of Fusarium oxysporum f. sp. cucumerinum. Biol Control 94: 37-46.

Shen W, Lin X, Gao N, Zhang H, Yin R, Shi W, Duan Z. 2008. Land use intensification affects soil microbial populations, functional diversity and related suppressiveness of cucumber Fusarium wilt in China's Yangtze River Delta. Plant Soil 306: 117-127

Sivasakthivelan P and Saranraj P. 2013. "Azospirillum and its formulations: A Review." Int J Microbiol Res 4 (3): 275-287.

Sriram S, Roopa KP, and Savitha MJ. 2011. "Extended shelf-life of liquid fermentation derived talc formulations of Trichoderma harzianum with the addition of glycerol in the production medium." Crop Protection 30 (10): 1334-1339.

Vasumathi S, Aiyanthan E and Nakkeeran S. 2016. Exploring the diversity of Trichoderma species and the synergistic activity of delivery systems for the management of cucumber under protected cultivation. J Mycol Pl Pathol. 46(4): 193-211

Vinodkumar S, Indumathi $\mathrm{T}$ and Nakkeeran S. 2017. Trichoderma asperellum (NVTA2) as a potential antagonist for the management of stem rot in carnation under protected cultivation. Biol. control. 113: 58-64

Yedidia, I, Srivastva AK, Kapulnik Y and Chet I. (2001). Effect of Trichoderma harzianum on microelement concentrations and increased growth of cucumber plants. Plant and soil, 235(2), 235-242

Yu JQ. 2001. Autotoxic potential of cucurbit crops: phenomenon, chemicals, mechanisms and means to overcome. $\mathbf{J}$ Crop Prod 4: 335-348

Zhang SS, Waseem R, Yang XM, Hu J, Huang QW, Xu YC, Liu XH, Ran W, Shen QR. 2008. Control of Fusarium wilt disease of cucumber plants with the application of a bio-organic fertilizer. Biol Fertil Soils 44: 1073-1080

\section{How to cite this article:}

Sreenayana, B. and Nakkeeran, S. 2019. Effect of Oil Based Formulation of Trichoderma spp. on Growth Parameters of Cucumber Seedlings. Int.J.Curr.Microbiol.App.Sci. 8(08): 200-209. doi: https://doi.org/10.20546/ijcmas.2019.808.024 